\title{
Weed infestation and factors affecting weed incidence in spring cereals in Finland - a multivariate approach
}

\author{
JUKKA SALONEN
}

\begin{abstract}
SALONEN, J. 1993. Weed infestation and factors affecting weed incidence in spring cereals in Finland - a multivariate approach. Agric. Sci. Finl. 2: 525-536. (Agric. Res. Centre of Finland, Inst. PI. Prot., FIN31600 Jokioinen, Finland.)

Weed vegetation of spring cereal fields in southern and central Finland was analyzed by ordination methods to provide a community level description of weed populations. Attention was paid particularly to the relative importance of environmental factors affecting weed incidence such as crop management, soil properties and weather conditions. A data set of 33 weed taxa from 252 fields was subjected to both indirect and direct gradient analysis. Indirect ordination was obtained with correspondence analysis (CA), and direct gradient analyses were performed with redundancy analysis (RDA) and with canonical correspondence analysis (CCA) relating environmental factors to the occurrence of weeds. Among several management factors, continuous herbicide use explained best the variation in the species composition of weed flora. Weed vegetation was also associated with soil type, moisture conditions and soil $\mathrm{pH}_{\mathrm{H}_{2} \mathrm{O}}$. Ordination diagrams visualized the species-environment interactions and detected characteristic weed species for different geographical regions. In addition to ordination analyses of weed flora, the level and structure of weed infestation are described. The density of weeds averaged 170 plants $\mathrm{m}^{-2}$ (median=124) and the air-dry weight of weeds $320 \mathrm{~kg}$ $\mathrm{ha}^{-1}($ median=183). The average weed density was the same in different soil types, but the weed biomass was lower in clay soils than in coarse mineral and organic soils.
\end{abstract}

Key words: broad-leaved weeds, ordination, barley, oats, wheat, canonical correspondence analysis, CA, CCA, RDA, CANOCO

\section{Introduction}

Arable fields are continuously subjected to different agricultural measures particularly in annual crops. Although many weed species are adapted to the prevailing conditions, the constantly changing habitat selectively affects weed communities and, consequently, changes the weed flora (RADEMACHER et al. 1970, REUSS 1981, MAHN 1984, CHANCELLOR 1985, LÉGÈRE et al. 1993).

Weed flora in spring cereals was investigated during 1982-84 in Finland (ERVIÖ and SALONEN
1987). Attention was paid particularly to the changes in weed infestation by comparing the data with the previous study from the 1960s (MUKULA et al. 1969). The occurrence of individual weed species was related to several explanatory variables by the analysis of variance and regression techniques. These methods are appropriate if detailed responses of particular weed species to explanatory factors are studied. The problem was, however, to give a summary of the relative importance of factors affecting the weed incidence. Therefore, the data from weed survey was subjected to ordination 
analyses which have proved to be appropriate for community level description of weed vegetation (TER BRAAK 1987a).

Multivariate analysis of community data is frequently applied in ecological studies to summarize the information in samples-by-species data matrices (GAUCH 1982). In weed science, the multivariate approach is feasible to describe and predict the response of weed vegetation to farming practices (POST 1988). Multivariate methods in ecology can be divided into three groups (JONGMAN et al. 1987): direct gradient analysis (regression), indirect gradient analysis (ordination) and classification (cluster analysis). Indirect methods analyze the species data only, whereas species-environment interactions can be analyzed simultaneously by direct methods.

In this paper, the weed survey data from 19821984 was subjected to ordination analyses to give a community level description of weed flora in spring cereal fields. The objective was to find characteristic weed species in different geographical regions and to illustrate responses of weed vegetation to environmental factors. Furthermore, the level of weed infestation, proportion of the most abundant weed species and the occurrence of weeds in different soil types are reported.

\section{Material and methods}

A total of 267 spring cereal fields (barley, oats or wheat) in southern and central Finland were studied during 1982-1984. In each field there were 4 to 5 sample plots of $0.25 \mathrm{~m}^{-2}$ in size from which the above-ground occurrence of 33 weed species (Table 1) or, in fact, weed taxa was assessed in late July by counting the number and weighing the airdry biomass of weeds. The sample plots were not sprayed with herbicides. Frequency of weeds (Table 1) denotes the proportion of the fields where the particular weed species was observed out of the all fields studied. Detailed information of the survey and the occurrence of weed species has been given by ERVIÖ and SALONEN (1987).

Data on factors involved in each field was collected either by observing, measuring or by interviewing the farmer. Twelve factors describing either the current crop, crop rotation, soil properties or climate (Table 2) were used as environmental variables in the CCA. The factors were chosen from among the 21 factors studied in the regression analysis and considered the most important (ERVIÖ and SALONEN 1987). The survey localities were grouped into three regions based on their geographical locations: South-western Finland (SW), eastern part of central Finland (CE) and western part of central Finland (CW).

Features of regression analysis and ordination are integrated in canonical ordination techniques (JoNGMAN et al. 1987). These techniques provide a direct analysis of species-environment interactions which was earlier possible only by regression methods. 'Canonical correspondence analysis' (CCA) by TER BRAAK (1986) is probably the most common canonical ordination technique currently applied in various ecological studies (BIRKS and Austin 1992). CCA and the related indirect technique 'correspondence analysis' (CA) (GAUCH 1982) have been applied also in agricultural research (JuKOla-Sulonen 1983, WentworTh et al. 1984, Post 1986, SiEPEL et al. 1989, PYŠEK and LEPŠ 1991, DALE et al. 1992). $\mathrm{CA}$ and CCA fit the unimodal curve to the species-environment data, whereas a linear response model between species data and environmental variables can be fitted by the 'redundancy analysis' (RDA). The ordination techniques mentioned above are all available in the computer program CANOCO (TER BRAAK 1987b).

Environmental variables were either qualitative (nominal scale) or quantitative (interval scale) (Table 2). The crop rotation was considered cereal dominant if a cereal crop had been grown at least for three years of the previous four years. Otherwise it was classified as mixed rotation. The use of herbicides indicates only the intensity of chemical weed control, not the type of herbicides applied during the last nine years. The soil $\mathrm{pH}_{\mathrm{H}_{2} \mathrm{O}}$ was measured from the top 0-20 cm layer. The soil type of fields was classified into three categories: clay (clay content $>30 \%$ ), organic ( $>20 \%$ organic matter) and coarse mineral soils. The subjective assessment of soil moisture was primarily based on the soil type and the drainage of the field. Nominal type environmental factors were transformed into binary dummy variables. Due to missing values of explanatory factors, some sample fields had to be excluded, since missing data are not accepted in the CANOCO run. Thus, a final data set consisted of 
Table 1. Frequency, the effective number of occurrences (N2) and average biomass production of the 33 weed species studied in 252 spring cereal fields. Frequency denotes the proportion of the fields where the species was found. The $\mathrm{N} 2$ value obtained from the CANOCO run is based on the weighted averages of weed densities and it indicates the number of fields where the species was abundant. Air-dry biomass indicates the average infestation of the species in those fields it was found.

\begin{tabular}{|c|c|c|c|c|}
\hline Weed taxa & Codel) & $\begin{array}{c}\text { Frequency } \\
\%\end{array}$ & $\mathrm{~N} 2$ & $\begin{array}{c}\text { Biomass } \\
\mathrm{g} \mathrm{m}^{-2}\end{array}$ \\
\hline Chenopodium album $\mathrm{L}$. & CHEAL & 87 & 163 & 5.0 \\
\hline Galeopsis spp. L. & GAESS & 85 & 166 & 6.1 \\
\hline Viola arvensis MURRAY & VIOAR & 85 & 146 & 1.0 \\
\hline Stellaria media (L.) VILL. & STEME & 81 & 155 & 2.8 \\
\hline Fallopia convolvulus (L.) Á. LÖVE & POLCO & 61 & 112 & 1.3 \\
\hline Erysimum cheiranthoides L. & ERYCH & 58 & 95 & 1.5 \\
\hline Lapsana communis $\mathrm{L}$. & LAPCO & 54 & 94 & 4.0 \\
\hline Polygonum aviculare $\mathrm{L}$. & POLAV & 52 & 71 & 0.5 \\
\hline Myosotis arvensis (L.) HILL & MYOAR & 52 & 66 & 0.5 \\
\hline Elymus repens (L.) GOULD & AGRRE & 51 & 92 & 13.0 \\
\hline Spergula arvensis $\mathrm{L}$. & SPRAR & 46 & 68 & 2.9 \\
\hline Fumaria officinalis $\mathrm{L}$. & FUMOF & 43 & 71 & 1.4 \\
\hline Galium spp. L. & GALSS & 35 & 57 & 1.0 \\
\hline Tripleurospermum inodorum SCHULTZ BIP. & MATIN & 32 & 34 & 0.7 \\
\hline Polygonum lapathifolium $\mathrm{L}$. & POLLA & 30 & 45 & 1.7 \\
\hline Sonchus arvensis $\mathrm{L}$. & SONAR & 27 & 43 & 2.8 \\
\hline Lamium spp. L. & LAMSS & 25 & 39 & 1.9 \\
\hline Matricaria matricarioides (LESS.) PORTER & MATMT & 18 & 23 & 1.9 \\
\hline Gnaphalium uliginosum $\mathrm{L}$. & GNAUL & 18 & 15 & 0.1 \\
\hline Capsella bursa-pastoris (L.) MEDIK. & CAPBP & 17 & 23 & 0.3 \\
\hline Ranunculus repens $\mathrm{L}$. & RANRE & 17 & 13 & 0.2 \\
\hline Thlaspi arvense $\mathrm{L}$. & THLAR & 16 & 21 & 0.8 \\
\hline Equisetum spp. L. & EQUSS & 13 & 26 & 2.1 \\
\hline Brassica rapa L. ssp. oleifera DC. (volunt.) & BRSRO & 13 & 25 & 4.0 \\
\hline Poa annua $\mathrm{L}$. & POAAN & 13 & 14 & 0.5 \\
\hline Brassica spp. L. & BRSSS & 12 & 15 & 4.2 \\
\hline Rumex spp. L. (Sorrels) & RUMSS & 12 & 14 & 0.7 \\
\hline Achillea spp. L. & ACHSS & 5 & 11 & 2.1 \\
\hline Cirsium arvense (L.) SCOP. & CIRAR & 5 & 7 & 2.0 \\
\hline Sonchus spp. L. (S. asper, S. oleraceus) & SONSS & 4 & 5 & 9.4 \\
\hline Urtica spp. L. & URTSS & 2 & 1 & 0.5 \\
\hline Avena fatua $\mathrm{L}$. & AVEFA & 1 & 2 & 9.4 \\
\hline Stachys palustris $\mathrm{L}$. & STAPA & 1 & 1 & 3.0 \\
\hline
\end{tabular}

1) Weed codes are according to the BAYER standard (BAYER 1992).

252 fields. The geographical regions were used as environmental variables in RDA, and as covariables in partial CCA.

Ordination analyses were performed with the CANOCO program (TER BRAAK 1987b) applying CA, CCA and RDA. Ordination diagrams (speciesenvironment biplots) were drawn with the CANODRAW program (ŠMILAUER 1990). The relationship between the weed communities and environmental variables is displayed with the first two ordination axes. Only the central area of the diagram is shown to improve the visibility of species near the origin. Consequently, some species and environmental variables lie outside the drawn area (Figs. 4 and 5).

Due to the skewed distribution of the response values (weed density and weed biomass) the weed data was log-transformed $(\ln (\mathrm{y}+1))$ in the CANOCO run. Species diversity was described by the N2 value from the CANOCO output. The N2 
Table 2. Environmental variables subjected to the canonical correspondence analysis (CCA).

\begin{tabular}{|c|c|c|}
\hline Variable (scale) & Code & $\begin{array}{c}\text { Range or } \\
\text { No. of fields }\end{array}$ \\
\hline
\end{tabular}

\section{CROP VARIABLES \\ Cover, \% (interval) \\ Yield, $\mathrm{kg} \mathrm{ha}^{-1}$ (interval) \\ MANAGEMENT VARIABLES \\ Cereal dominance (nominal) \\ Cereals \\ Mixed rotation \\ Herbicide use during \\ 9 previous years (interval) \\ 0 years \\ 1 \\ 2 \\ 3 \\ 4 \\ 5 \\ 6 \\ 8 \\ 9}

COVER

$13-100$

YIELD

$520-7300$

CER

MIX

144

108

HERB

\section{SOIL VARIABLES}

Soil type (nominal)

Coarse
Clay
Organic

Moisture type (nominal)

Dry
Normal
Wet

Soil $\mathrm{pH}_{\mathrm{H}_{2} \mathrm{O}}$ (interval)

$\begin{array}{lr}\text { COARSE } & 110 \\ \text { CLAY } & 112 \\ \text { ORGANIC } & 30 \\ & \\ \text { DRY } & 40 \\ \text { NORMAL } & 199 \\ \text { WET } & 13\end{array}$

PH 4.85-7.65

CLIMATIC VARIABLES (between sowing and sampling)

Effective temperature

sum, DD (base $5^{\circ} \mathrm{C}$ ) (interval) ETS

281-857

Precipitation, mm (interval) PREC

40-222 where $\lambda$ is Simpson's diversity index, $\mathrm{n}_{\mathrm{i}}$ is the number of ith species in the population and $\mathrm{N}$ is the total number of all $\mathrm{S}$ species in the population.

\section{Results}

\section{Occurrence of weeds}

The weed density averaged 170 plants $\mathrm{m}^{-2}(\mathrm{SE}=10$, median=124) and the biomass production $320 \mathrm{~kg}$ $\mathrm{ha}^{-1}(\mathrm{SE}=23$, median=183). The total weed biomass correlated weakly $(\mathrm{r}=0.54, \mathrm{P}<0.01)$ with the total weed density. A typical weed density was 50-150 weeds $\mathrm{m}^{-2}$, whereas the biomass production was distributed more evenly into different classes (Fig. 1). Weed densities in different soil types were at the same level, but the biomass production of weeds was on average lower in clay soils than in coarse mineral or organic soils (Fig. 2).

Only ten weed species occurred in more than half of the fields studied (Table 1). The ranking order based on the $\mathrm{N} 2$ value was slightly different from the frequency order. The N2 value for samples averaged 6.9 (range 2.1-13.4), i.e. on average there were seven relatively abundant weed species in each field.

Moreover, in order to emphasize the relative importance of different weed species, they were ranked according to their average biomass production (Table 1), and also with regard to their proportion of the total density and biomass of weeds (Fig. $3)$. The nine most dominant weeds constituted twothirds of the total weed infestation.

\section{Species-environment relationships}

value is analogous to Hill's N2 diversity number (HILL 1973). For samples, N2 is the inverse of Simpson's diversity index (LUDWIG and REYNOLDS 1988):

$$
\mathrm{N} 2=1 / \lambda
$$

where

$$
\lambda=\sum_{i=1}^{\mathrm{s}}\left(\mathrm{n}_{\mathrm{i}} / \mathrm{N}\right)^{2}, \mathrm{i}=1,2,3 \ldots \ldots \mathrm{S}
$$

CCA and RDA were applied to the species ordination in the three geographical regions. Both techniques characterized the typical weed species of different regions illustrated here by the RDA diagram (Fig. 4) which provided a slightly better separation of samples and weed species than the CCA diagram.

The CCA ordination diagrams for the density and biomass data were very much alike. Thus, only 

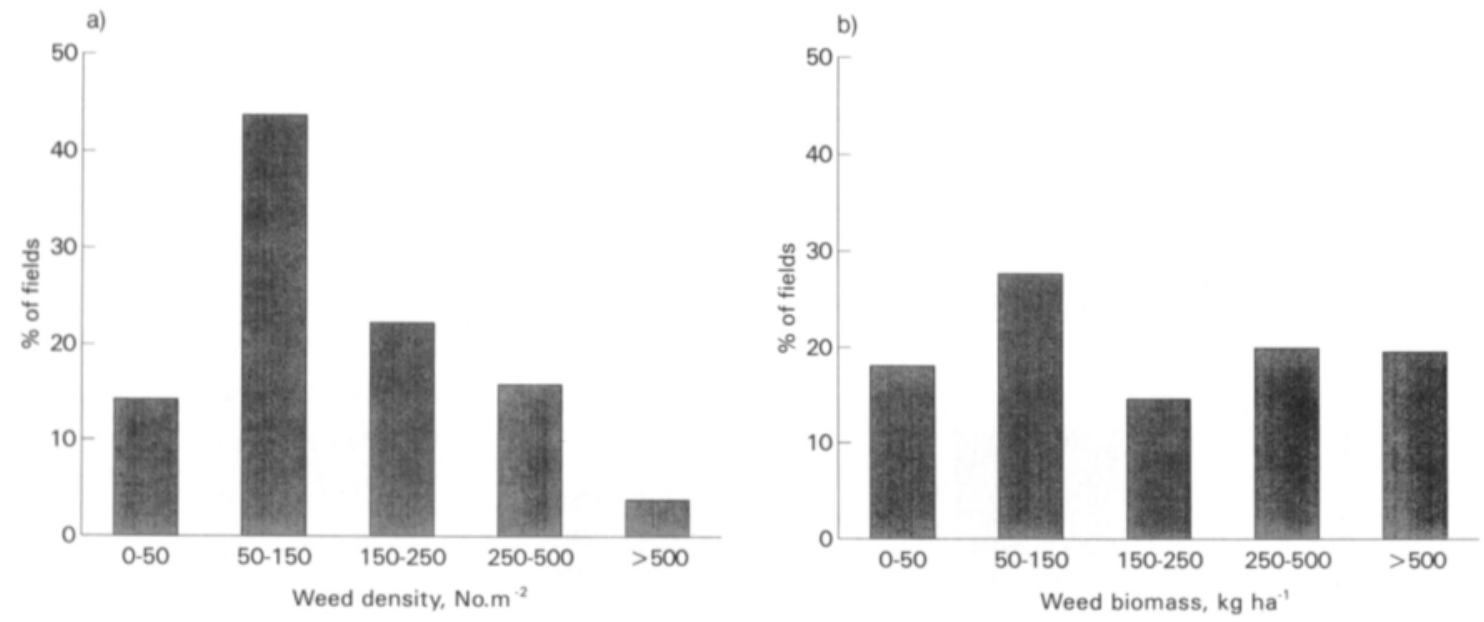

Fig. 1. Distribution of spring cereal fields into weed infestation classes according to a) weed density and b) air-dry biomass. Assessment was made from unsprayed sample plots in July.

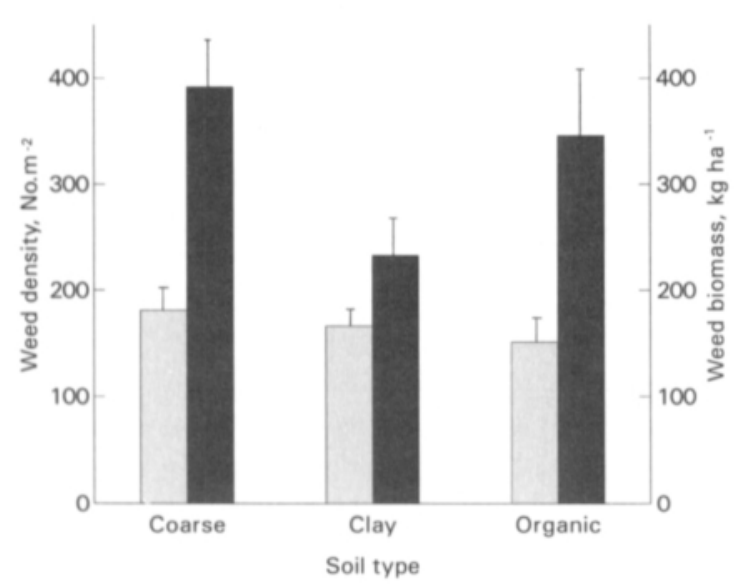

Fig. 2. Weed infestation in different soil types. The mean weed density (left bar) and air-dry biomass (right bar) in unsprayed fields. Vertical line indicates the standard error of the mean.

the diagram for biomass data is shown, since it provided somewhat higher eigenvalues (Table 3, Fig. 5). Eigenvalue denotes the dispersion of the species scores along the ordination axis, and is thus a measure of importance of the ordination axis (JONGMAN et al. 1987).
The first canonical axis ("x-axis") extracted by CCA was closely related to the management practices, as indicated by long vectors and nearby centroids of nominal factors (Fig. 5) and by high interset correlations with the axis (Table 4). Continuous herbicide application proved to be the most "effective" factor explaining the composition of weed flora.

The second axis ("y-axis") was associated with soil variables, particularly $\mathrm{pH}$, and with climatic factors, precipitation and effective temperature sum between sowing and sampling. Galeopsis spp. and Polygonum spp. occurred frequently in moist organic soils, whereas Sonchus spp., Poa annua and Lapsana communis thrived in coarse soils and warm and humid weather conditions which were typical of the eastern region of the survey.

Although the eigenvalues obtained by CCA were low, the first two canonical axes from the constrained ordination accounted for $49 \%$ of the total species-environment variation. In the analysis of weed density, the corresponding value was $53 \%$. Partial CCA with regions as covariables slightly reduced the explained variance. The first canonical axis was statistically significant $(\mathrm{P}=0.01$, Monte Carlo permutation test) in all analyses. 


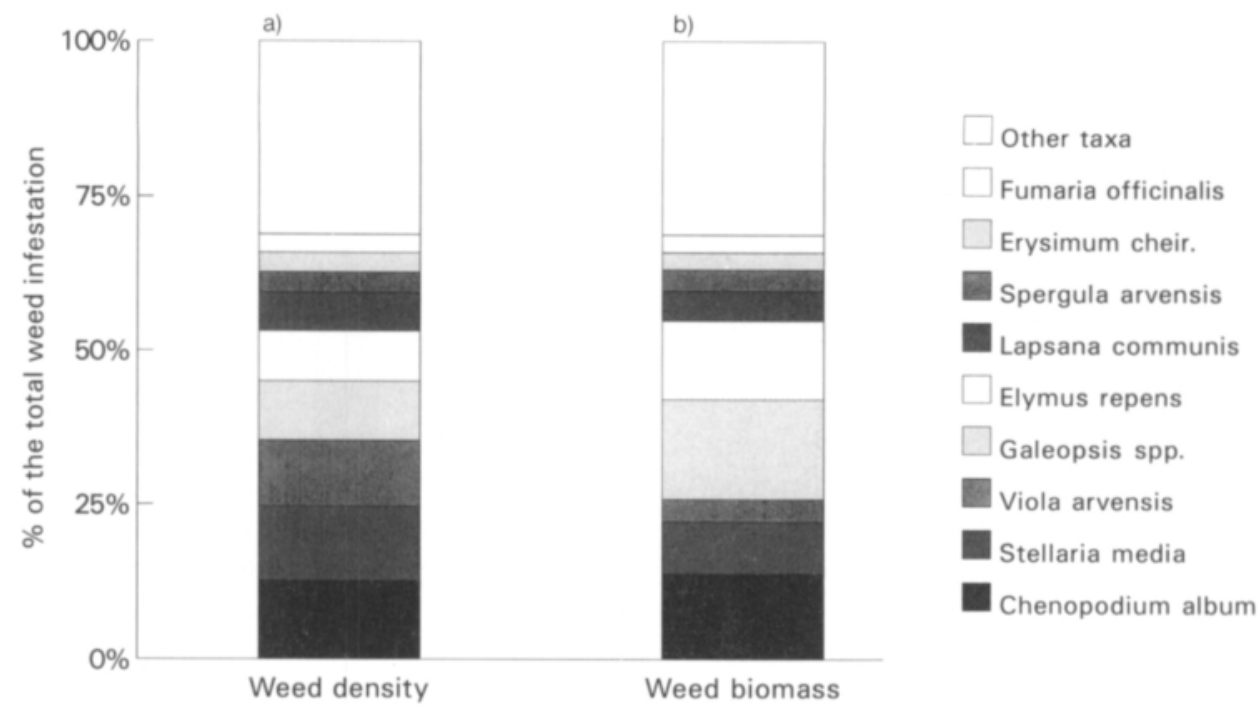

Fig. 3. Mean proportion (\%) of the most abundant weed species of (a) the total weed density and (b) weed biomass in unsprayed spring cereal fields. Assessment was made in July.

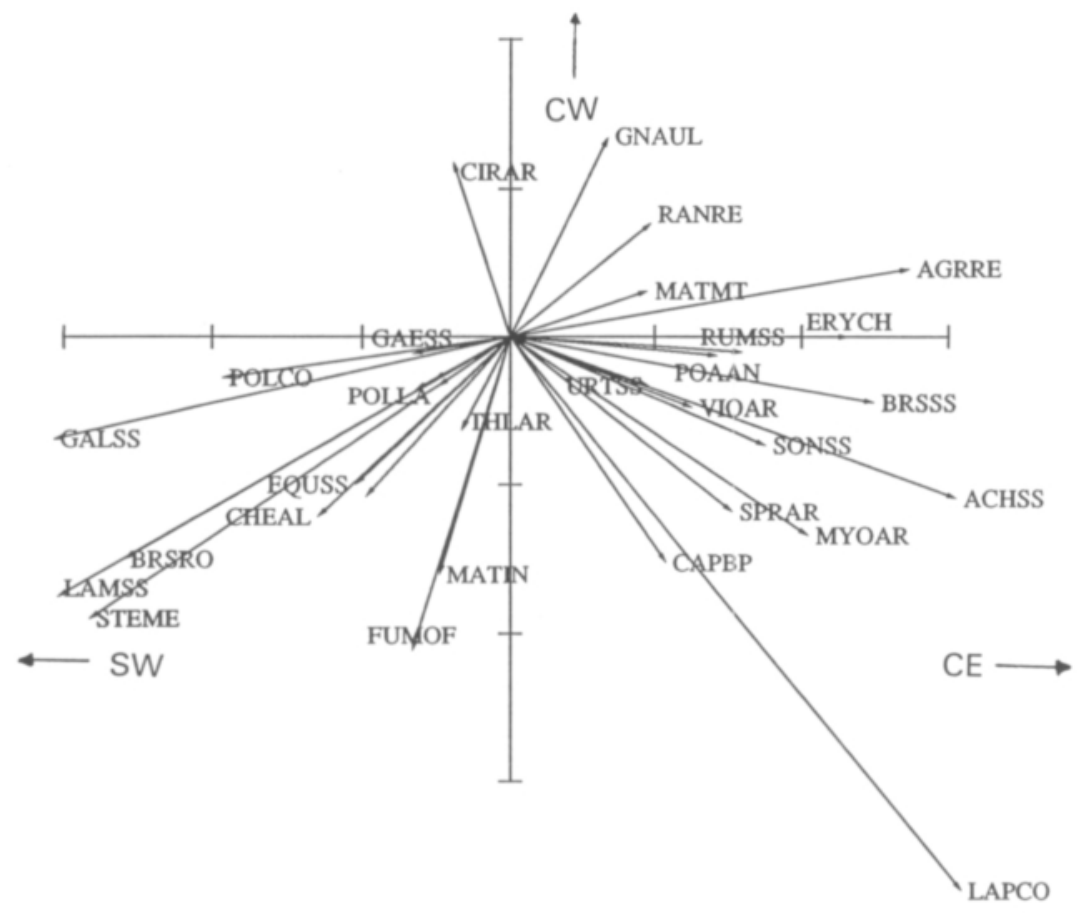

Fig. 4. Ordination diagram based on redundancy analysis (RDA) of weed densities describing indicator species for southwest (SW), central-east (CE) and central-west (CW) regions of Finland. Centroids of all regions lie outside the range of the diagram. Some species near the origin are not shown because of their overlapping position. 


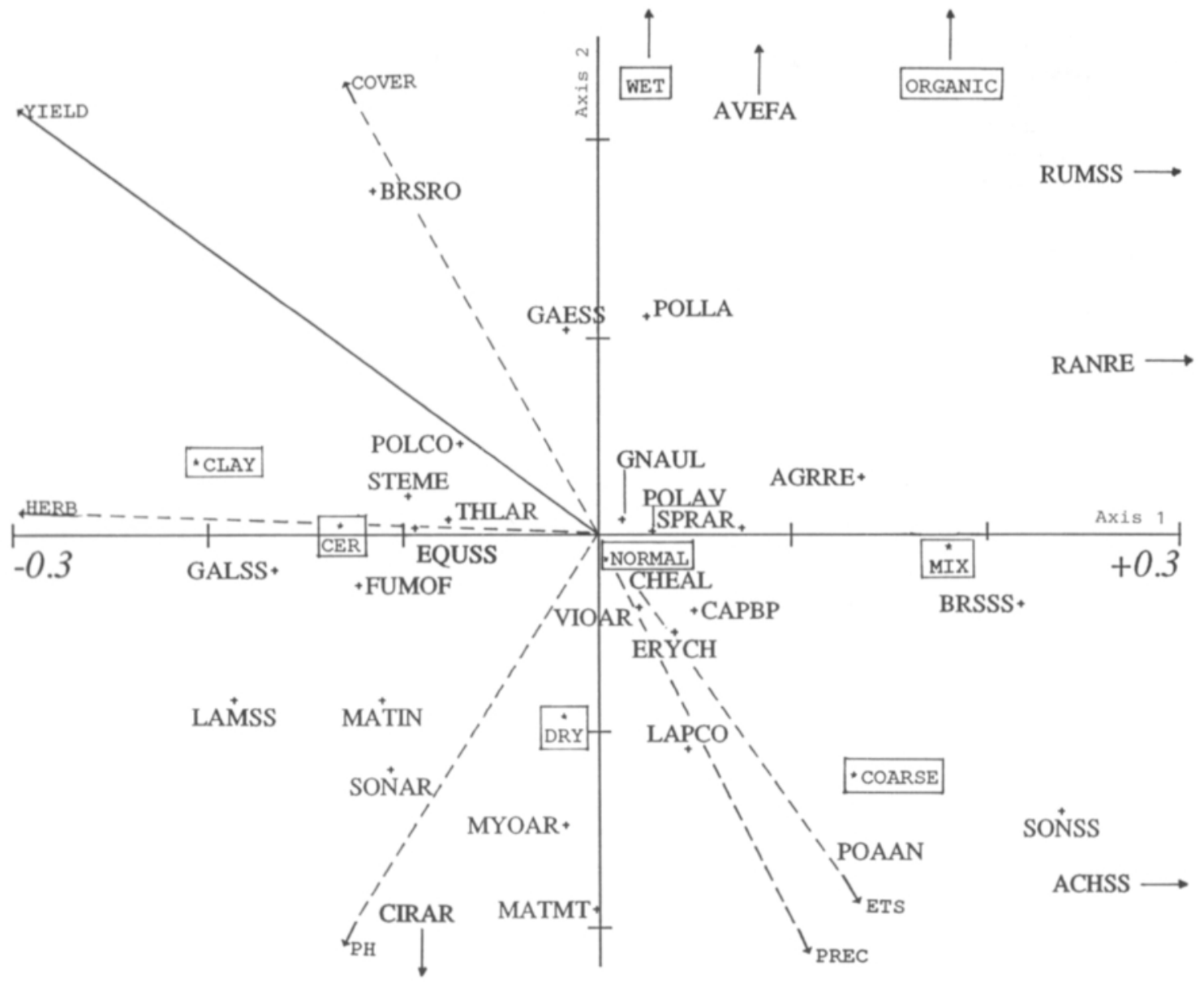

Fig. 5. Ordination diagram based on canonical correpondence analysis (CCA) of weed biomass data from 252 spring cereal fields. The end of dotted vectors lies outside the range of the diagram. Two species (STAPA, URTSS) near the origin are not shown because of their overlapping position with other species.

Key to abbreviations

Weed species: $\mathrm{ACHSS}=$ Achillea spp., AGRRE $=$ Elymus repens, $\mathrm{AVEFA}=$ Avena fatua, $\mathrm{BRSSS}=$ Brassica spp. , $\mathrm{BRSRO}=$ Brassica rapa ssp. oleifera, $\mathrm{CAPBP}=$ Capsella bursapastoris, $\mathrm{CHEAL}=$ Chenopodium album, $\mathrm{CIRAR}=$ Cirsium arvense, $\mathrm{EQUSS}=$ Equisetum $\mathrm{spp} ., \mathrm{ERYCH}=$ Erysimum cheiranthoides, $\mathrm{FUMOF}=$ Fumaria officinalis, $\mathrm{GAESS}=$ Galeopsis spp, GALSS = Galium spp., GNAUL = Gnaphalium uliginosum, LAMSS = Lamium spp., LAPCO = Lapsana communis, MATIN $=$ Tripleurospermum inodorum, MATMT $=$ Matricaria matricarioides, $\mathrm{MYOAR}=$ Myosotis arvensis, $\mathrm{POAAN}=$ Poa annua, $\mathrm{POLAV}=$ Polygonum aviculare, $\mathrm{POLCO}=$ Fallopia convolvulus, $\mathrm{POLLA}=$ Polygonum lapathifolium, $\mathrm{RANRE}=$ Ranunculus repens, RUMSS = Rumex spp., SONAR = Sonchus arvensis, $\mathrm{SONSS}=$ Sonchus spp., SPRAR = Spergula arvensis, STAPA = Stachys palustris, STEME = Stellaria media, THLAR $=$ Thlaspi arvense, URTSS $=$ Urtica spp., VIOAR $=$ Viola arvensis. Weed codes are according to the BAYER standard (BAYER 1992).

Explanatory factors: CER = Cereal-dominated rotation, CLAY $=$ Clay soil, COARSE $=$ Coarse soil, COVER $=$ Crop cover, DRY = Dry soil, ETS = Effectice temperature sum between sowing and sampling, HERB = Duration of herbicide use, $\mathrm{MIX}=$ Mixed crop rotation, $\mathrm{NORMAL}=$ Normal soil moisture, ORGANIC $=$ Organic soil, $\mathrm{PH}=\mathrm{Soil}_{\mathrm{pH}} \mathrm{H}_{2} \mathrm{O}, \mathrm{PREC}=$ Precipitation sum between sowing and sampling, WET $=$ Wet soil, YIELD = Crop yield. 
Table 3. Eigenvalues $\left(\lambda_{1-4}\right)$ corresponding to the first four ordination axes from Correspondence Analysis (CA) and Canonical Correspondence Analysis (CCA). Environmental values for CCA are given in Table 2. Partial analyses were performed with regions as covariables. Weed infestation values from 252 spring cereal fields were transformed with $\ln (y+1)$.

\begin{tabular}{lcccc}
\hline & \multicolumn{4}{c}{ Eigenvalues } \\
\cline { 2 - 5 } Ordination method & $\lambda_{1}$ & $\lambda_{2}$ & $\lambda_{3}$ & $\lambda_{4}$ \\
\hline \multirow{5}{c}{ Weed density data } \\
CA & 0.253 & 0.209 & 0.194 & 0.181 \\
CCA & 0.122 & 0.073 & 0.048 & 0.030 \\
Partial CCA & 0.076 & 0.056 & 0.037 & 0.030 \\
& \multicolumn{5}{c}{ Weed biomass data } \\
CA & 0.315 & 0.281 & 0.275 & 0.263 \\
CCA & 0.142 & 0.097 & 0.065 & 0.046 \\
Partial CCA & 0.101 & 0.066 & 0.063 & 0.046 \\
\hline
\end{tabular}

\section{Discussion}

The average weed density in spring cereal fields was relatively low, as in $58 \%$ of the fields the weed density remained below 150 plants $\mathrm{m}^{-2}$, and the median weed density was only 124 plants $\mathrm{m}^{-2}$. Since the density values showed a skewed distribution, the median value is a more appropriate measure to indicate the level of weed infestation in spring cereal fields. The results correspond to the present weed infestation levels found in field experiments in the Nordic countries (HALlgReN 1993, SALONEN 1993).

The weed flora was dominated by rather few species (Table 1, Fig. 3) which is a common phenomenon in intensified farming systems (NEURURER 1965, Callauch 1981, Albrecht and BACHTHALER 1988). The low number of abundant species makes e.g. the choice of herbicides easier.

Table 4. Inter-set correlations of environmental variables with the first four ordination axes from CCA for the weed biomass data. The two highest values of each axis are underlined.

\begin{tabular}{|c|c|c|c|c|}
\hline \multirow{2}{*}{$\begin{array}{l}\text { Factor group } \\
\text { VARIABLE }\end{array}$} & \multicolumn{4}{|c|}{ Axes } \\
\hline & $\begin{array}{c}1 \\
\lambda_{1}=0.142\end{array}$ & $\begin{array}{c}2 \\
\lambda_{2}=0.097\end{array}$ & $\begin{array}{c}3 \\
\lambda_{3}=0.065\end{array}$ & $\begin{array}{c}4 \\
\lambda_{4}=0.046\end{array}$ \\
\hline \multicolumn{5}{|l|}{ Crop \& Management } \\
\hline $\begin{array}{l}\text { COVER (of crop) } \\
\text { YIELD } \\
\text { CER(eal dominance) } \\
\text { MIX(ed rotation) } \\
\text { HERB(icide use) }\end{array}$ & $\begin{array}{r}-0.12 \\
-0.21 \\
-0.43 \\
0.43 \\
-0.56 \\
\end{array}$ & $\begin{array}{r}0.23 \\
0.14 \\
-0.01 \\
0.01 \\
0.01\end{array}$ & $\begin{array}{r}-0.15 \\
-0.18 \\
0.09 \\
-0.09 \\
0.17\end{array}$ & $\begin{array}{r}-0.01 \\
-0.04 \\
-0.19 \\
0.19 \\
0.08\end{array}$ \\
\hline \multicolumn{5}{|l|}{ Soil } \\
\hline $\begin{array}{l}\text { Soil type } \\
\text { COARSE } \\
\text { CLAY } \\
\text { ORGANIC }\end{array}$ & $\begin{array}{r}0.35 \\
-0.47 \\
0.18\end{array}$ & $\begin{array}{r}-0.31 \\
0.08 \\
\underline{0.38} \\
\end{array}$ & $\begin{array}{r}-0.07 \\
0.04 \\
0.18\end{array}$ & $\begin{array}{r}-0.23 \\
0.15 \\
0.14\end{array}$ \\
\hline \multicolumn{5}{|l|}{ Soil moisture } \\
\hline $\begin{array}{l}\text { DRY } \\
\text { NORMAL } \\
\text { WET }\end{array}$ & $\begin{array}{l}0.02 \\
0.01 \\
0.01\end{array}$ & $\begin{array}{r}-0.11 \\
0.03 \\
0.23\end{array}$ & $\begin{array}{l}0.10 \\
0.18 \\
0.15\end{array}$ & $\begin{array}{r}\frac{0.24}{0.19} \\
-0.04\end{array}$ \\
\hline PH (soil) & -0.22 & $\underline{-0.45}$ & $\underline{-0.19}$ & 0.09 \\
\hline \multicolumn{5}{|l|}{ Climate } \\
\hline $\begin{array}{l}\text { ETS } \\
\text { PREC(ipitation) }\end{array}$ & $\begin{array}{l}0.18 \\
0.16\end{array}$ & $\begin{array}{l}-0.28 \\
-0.33\end{array}$ & $\begin{array}{l}0.09 \\
0.26 \\
\end{array}$ & $\frac{-0.29}{0.06}$ \\
\hline
\end{tabular}


The mean proportion of individual weed species out of the total weed density and biomass in each field (Fig. 3) indicated that Chenopodium album, Stellaria media and Viola arvensis are the most dominant species in terms of weed density whereas, Galeopsis spp., C. album and Elymus repens were the most dominant species in terms of biomass production. Furthermore, Stellaria media and Viola arvensis had a higher proportion in densities than in biomass.

The most aggressive weed species such as Galeopsis spp. and volunteer turnip rape (BRSRO) were detected both by their proportion of total weed biomass (Fig. 3) and along the crop cover vector (COVER) in the ordination diagram (Fig. 5).

Differences in weed abundances and weed biomass production between soil types (Fig. 2) infer both to growth conditions and species composition. Apparently, differences in weed growth between soil types are also reflected in yield responses of the crop. Indeed, yield responses of cereals have been found to be the lowest in clay soils (JENSEN 1985, HALLGREN 1989).

Ordination analysis provided easily interpretable results which were in agreement with the conclusions based on the regression analysis (ERVIÖ and SALONEN 1987) with regard to the most important factors affecting the occurrence of weeds. However, the relative importance of different factors was more clearly and easily pointed out by the ordination analysis than by the regression analysis. A particular advantage in applying ordination analyses is that the CCA ordination diagrams are not in any way hampered by high correlations between weed species or between environmental variables (TER BRAAK 1987c).

The most frequent species like Chenopodium album and Viola arvensis located near the origin of the ordination diagram (Fig. 5). These species were found in all field types indicating that they are well adapted to agricultural ecosystem.

Each geographical regions had its characteristic weed species as was also concluded earlier with the analysis of variance (ERVIÖ and SALONEN 1987). Some less frequent species like Achillea spp., and Galium spp. were particularly associated with certain regions (Fig. 4).
The results achieved with RDA (Fig. 4) and CCA (Fig. 5) can be combined. Typical weed species for cereal-dominated rotations with frequent use of herbicides were Lamium spp., Galium spp., Fumaria officinalis, Tripleurospermum inodorum and volunteer turnip rape. In addition, Lamium spp. and Galium spp. thrived in clay soils as reported also by MuKUla et al. (1969) and ANDREASEN et al. (1991). Indeed, cereal-dominated crop rotations were common in south-western Finland (SW) where most of the fields were clay soils and herbicides were frequently used. In this region, turnip rape and winter cereals are common crops in rotation, thus promoting the occurrence of volunteer oilseed rape and Tripleurospermum inodorum which is a common species in winter cereals (RAATIKAINEN et al. 1978).

Long-term use of herbicides has evidently selected the weed populations in south-western Finland towards the more tolerant species like Galium spp., Lamium spp. and Tripleurospermum inodorum. Indicator species for geographical regions hopefully help e.g. advisory services to direct general control recommendations to different regions.

Some weed species were typical of central Finland. Rumex spp. (R. acetosa and R. acetosella) and Ranunculus repens are associated with grassland (RAATIKAINEN and RAATIKAINEN 1975) which is a common crop in rotations in central Finland. Polygonum spp. were characteristically in organic soils which were most often found in central Finland.

Both management practices and soil properties affected the weed vegetation. However, the effects of individual environmental variables should be interpreted with caution due to the confounded nature of several factors associated with crop rotation and crop management. Similar conclusions were drawn from the regression analysis (ERVIÖ and SALONEN 1987) and in other weed surveys (STREIBIG et al. 1984, ANDREASEN et al. 1991, DALE et al. 1992).

In general, the possibilities to draw definite conclusions from this kind of weed survey data seem to be limited due to the complex cropping history in each field as discussed also by COUSENS et al. (1988). Relatively high eigenvalues of the third and fourth axes (Table 4) indicated the complex nature 
of weed communities which was impossible to explain with the few environmental variables chosen. Obviously, more detailed information on the cropping history, like crop rotation, type of herbicides used and their control efficacy, is needed to describe better the responses of weed flora to environmental conditions. Forward selection of environmental variables in CANOCO appeared to be rather liberal in judging the variables statistically significant. This is a typical shortcoming of stepwise selection of variables because the overall size of the test is not controlled (TER BRAAK 1990).

Low eigenvalues of ordination axes reveal either short environmental gradients in cereal fields or the plasticity of most weed species to grow in diverse conditions. Low eigenvalues are also the consequence of few abundant species which occurred in most fields. As the number of observed weeds was limited to 33 taxa, the study probably ignored some weed species that might have had an explanatory power in the ordination analysis. Nevertheless, ordination diagrams illustrated some clear patterns in weed communities and related environmental factors and agricultural practices to the weed data. Ordination techniques detected groups of weed species similar to those by the TWINSPAN classification of the same data (SALONEN 1990).

In conclusion, weed flora showed a response particularly to management practices. Herbicide use affected most the composition of weed flora. This should be considered in planning the crop rotations and long-term weed control measures. The ordination analysis detected also an evident relationship between the weed composition and soil properties in the field. Some of these properties, e.g. soil pH, can be manipulated if neccessary.

Simultaneous analysis of several weed species with environmental factors and plotting of data gave a better community level description on weed incidence than regression analysis (ERVIÖ and SALONEN 1987) which rather provided a deeper but narrower insight into weed vegetation and individual weed species. Still, the ordination analysis should be regarded both as a hypothesis provoking and explaining approach. Nevertheless, it is appropriate to start the analysis of data from weed surveys with ordination analysis and to continue, if necessary, with regression analysis to solve more detailed hypotheses.

Acknowledgements. I am grateful to Drs Ben J. Post for arrangements during my visit at the VPO department of the Wageningen Agricultural University for two months in 1988 and to Dr Caspar Looman for supervising the application of ordination techniques and for valuable comments on the manuscript. Comments and corrections by Dr Jari Oksanen are also warmly acknowledged. My visit to the Netherlands was financed by the Academy of Finland and by the Research and Science Foundation of Farmos.

\section{References}

Albrecht, H. \& Bachthaler, G. 1988. Die Segetalflora zweier bayerischer Ackerstandorte 1986/87 im Vergleich zu Untersuchungsergebnissen von 1955/56 bzw. 1965. Z. Pfl.krankh. Pfl.shutz, Sonderh. 11: 163-174.

Andreasen, C., Streibig, J.C. \& HaAs, H. 1991. Soil properties affecting the weed distribution of 37 weed species in Danish fields. Weed Res. 31: 181-187.

BAYER 1992. Important crops of the world and their weeds. 2nd ed. BAYER AG. Leverkusen. 1681 p.

Birks, H.J.B. \& Austin, H.A. 1992. An annotated bibliography of canonical correspondence analysis and related constrained ordination methods 1986-1991. Univ. Bergen, Norway. 29 p.

CALlauch, R. 1981. Vergleich der Segetalvegetation auf 'konventionell' und 'biologisch' bewirtschafteten Äckern in SONiedersachsen. Z. Pfl.krankh. Pfl.shutz, Sonderh. 9: 85-95.

Chancellor, R.J. 1985. Changes in the weed flora of an arable field cultivated for 20 years. J. Appl. Ecol. 22: 491-501.

Cousens, R., Marshall, E.J.P. \& Arnold, G.M. 1988. Problems in the interpretation of effects of herbicides on plant communities. BCPC Mono. No. 40 Environmental Effects of Pesticides. p. 275-282.

Dale, M.R.T., Thomas, A.G. \& John, E.A. 1992. Environmental factors including management practices as correlates of weed community composition in spring seeded crops. Can. J. Bot. 70: 1931-1939.

Erviō, L.-R. \& SAlonen, J. 1987. Changes in weed population of spring cereals in Finland. Ann. Agric. Fenn. 26: 201-226.

GAUCH, H.G. 1982. Multivariate analysis in community ecology. Cambridge University Press, Cambridge. 298 p.

Hallgren, E. 1989. Influence of different factors on the effect of spraying cereals in the spring with Oxitril 4 as regards weeds and grain yield. 2 . Influence of crop, de- 
velopmental stage, prevailing conditions, geographical and climatic situation, soil type, organic content and $\mathrm{N}$-rate on weed stand and effect on weeds. Composition of weed stand at different relative yields. Proc. 29th Swed. Weed Contr. Conf. - Weeds and Weed Control, Uppsala. p. 39-74.

- 1993. Förändras ogräsfloran och verkan av ett ogräsmedel (Oxitril 4) med tiden?. Proc. 34:e svenska växtskyddskonferensen. Ogräs och ogräsbekämp., Uppsala. Rapp. p. 15-38.

HiLl, M.O. 1973. Diversity and evenness: an unifying notation and its consequences. Ecology 54: 427-432.

JENSEN, P.K. 1985. A review of yield responses to weed control in one thousand spring barley experiments. Proc. 1985 British Crop Prot. Conf. - Weeds 2: 687-692.

Jongman, R.H.G., Ter BraAK, C.J.F. \& VAN Tongeren, O.F.R. 1987. Data analysis in community and landscape ecology. Pudoc, Wageningen. 299 p.

JuKola-Sulonen, E.-L. 1983. Vegetation succession of abandoned hay fields in central Finland - a quantitative approach. Univ. of Helsinki. Communic. Inst. Forestalis Fenn. 112. 85 p. (Diss.)

Légère, A., Lemieux, C., Simard, R.R. \& Lapierre, C. 1993. Response of weed communities to fertility and tillage. Proc. 8th EWRS Symp. Quantitative Approaches of Weed and Herbicide Research. 1: 41-48.

LudwiG, J.A. \& REYNOLDS, J.F. 1988. Statistical ecology - a primer on methods and computing. J. Wiley \& Sons, New York. 337 p.

Marn, E.G. 1984. The influence of different nitrogen levels on the productivity and structural changes of weed communities in agroecosystems. Proc. 7th Int. Symp. on Weed Biology and Systematics., Paris. p. 421-429.

Mukula, J., RaAtikainen, M., LallukKa, R. \& RaAtikainen, T. 1969. Composition of weed flora in spring cereals in Finland. Ann. Agric. Fenn. 8: 59-109.

NeuruRER, H. 1965. Wandlungen in der Unkrautflora im Zuge von Standortsänderungen und als Folge von Bekämpfungsmassnahmen. Z. Pfl.krankh. Pfl.shutz, Sonderh. 3: 39-43.

Post, B.J. 1986. Factors of influence on the development of an arable weed vegetation. Proc. EWRS Symp. Economic Weed Control. p. 317-325.

- 1988. Multivariate analysis in weed science. Weed Res. 28: 425-430.

PYšeK, P. \& LEPS, J. 1991. Response of a weed community to nitrogen fertilization: a multivariate analysis. J. Vegetation Sci. 2: 237-244.

RaAtikainen, M. \& RaAtikainen, T. 1975. Heinänurmien sato, kasvilajikoostumus ja sen muutokset. Summary: Yield, composition and dynamics of flora in grassland for hay in Finland. Ann. Agric. Fenn. 14: 57-191.

— , RaAtikainen, T. \& Mukula, J. 1978. Weed species, frequencies and densities in winter cereals in Finland. Ann. Agric. Fenn. 17: 115-142.
Rademacher, B., Кoch, W. \& Hurle, K. 1970. Changes in the weed flora as the result of continuous cropping of cereals and the annual use of the same weed control measures since 1956. Proc. 10th Brighton Weed Conf. p. 1-6.

Reuss, H.-U. 1981. Untersuchung des Einflusses produktionstechnischer und ökologischer Faktoren auf die quantitative und qualitative Veränderung der standörtlichen Unkrautflora auf Ackerland. Technischen Universität München. 116 p. (Diss.).

SALONEN, J. 1990. Analysis of weed data with advanced multivariate techniques. Nordic post-graduate course in crop production science. Garpenberg, Sweden. Mimeogr. 18 p. (Available at Agric. Res. Centre of Finland, Inst. PI. Protect.)

- 1993. Performance of reduced herbicide doses in spring cereals. Agric. Sci. Finl. 2: (in press).

Siepel, H., Meuer, J., Mabelis, A.A. \& den Boer, M.H. 1989. A tool to assess the influence of management practices on grassland surface macrofaunas. J. Appl. Entomol. 108: 271-290.

ŠMILAUER, P. 1990. CANODRAW - a companion program to CANOCO for publication-quality graphical output. Microcomputer Power, Ithaca, New York. 33 p.

Streibig, J.C., Gottschau, A., Dennis, B., HaAs, H. \& MølGAARD, P. 1984. Soil properties affecting weed distribution. Proc. 7th Int. Symp. on Weed Biology, Ecology and Systematics, Paris. p. 147-154.

TER BRAAK, C.J. 1986. Canonical correspondence analysis: a new eigenvector technique for multivariate direct gradient analysis. Ecology 67: 1167-1179.

- 1987a. Unimodal models to relate species to environment. Wageningen Agricultural Univ. 152 p. (Diss.).

- 1987b. CANOCO - a FORTRAN program for Canonical Community Ordination. Microcomputer Power, Ithaca, New York. 95 p.

$-1987 \mathrm{c}$. The analysis of vegetation-environment relationships by canonical correspondence analysis. Vegetatio 69: 69-77.

- 1990. Update notes: CANOCO version 3.10. Agricultural Mathematics Group, Wageningen. 35 p.

Wentworth, T.R., Conn, J.S., SKroch, W.A. \& MrozeK, E. 1984. Gradient analysis and numerical classification of apple orchard weed vegetation. Agric. Ecosyst. Envir. 11: 239-251.

\section{Manuscript received June 1993}

Jukka Salonen

Agricultural Research Centre of Finland

Institute of Plant Protection

FIN - 31600 Jokioinen, Finland 


\title{
SELOSTUS
}

\section{Kevätviljapeltojen rikkakasvillisuus ja rikkakasvien esiintymiseen vaikuttavien tekijöiden tarkastelu ordinaatioanalyysillä}

\author{
JUKKA SALONEN \\ Maatalouden tutkimuskeskus
}

Kevätviljapeltojen rikkakasvillisuutta analysoitiin ordinaatiomenetelmillä ja kuvattiin koordinaatistokuvilla. CANOCOohjelman monimuuttujamenetelmillä pystyttiin erottelemaan eri maantieteellisille alueille tyypillisiä rikkakasvilajeja ja niiden esiintymiseen vaikuttavia tekijöitä.

Viljelytekniset toimet kuten yksipuolinen viljanviljely ja jatkuva herbisidien käyttö suosivat mm. mataroiden, peippien, pihatähtimön ja peltoemäkin esiintymistä. Nämä lajit esiintyivät yleisimmin Lounais-Suomessa. Keski-Suomen tyypillisiä lajeja olivat mm. linnunkaali, juolavehnä ja kärsämöt. Maan happamuus ja maalaji olivat tärkeimpiä kasvualustaan liittyviä tekijöitä, jotka vaikuttivat rikkakasvuston koostumukseen. Jatkuva herbisidien käyttö oli merkittävin yksittäinen rikkakasvillisuuden koostumusta selittävä tekijä, joskin eri ympäristötekijöiden vaikutuksia rikkakasvilajeihin ei pystytty täysin erottamaan toisistaan.

Rikkakasvien keskimääräinen kasvutiheys oli $170 \mathrm{kpl} / \mathrm{m}^{2}$ (mediaani $124 \mathrm{kpl} / \mathrm{m}^{2}$ ). Rikkakasvien tuottama maanpäällinen ilmakuiva biomassa oli keskimäärin $320 \mathrm{~kg} / \mathrm{ha}$ (mediaani 183 $\mathrm{kg} / \mathrm{ha}$ ). Rikkakasvien keskimääräinen kasvutiheys ei vaihdellut eri maalajeilla, mutta kasvit tuottivat enemmän biomassaa karkeilla kivennäismailla ja turvemailla kuin savimailla. Tehokkaimpia biomassan tuottajia olivat pillikkeet, jauhosavikka ja juolavehnä.

Rikkakasvikartoituksen lajisto koostui 33 ennalta valitusta lajista. Tyypillisesti kunkin pellon rikkakasvillisuus koostui muutamasta lajista. Yksittäisten lajien suhteellista runsautta kuvaavan N2-diversiteetin perusteella pelloilla esiintyi keskimäärin seitsemän kasvutiheydeltään $\left(\mathrm{kpl} / \mathrm{m}^{2}\right)$ merkittävää lajia. Lajisto jakautui lähes kaikilla viljelyksillä esiintyviin lajeihin (jauhosavikka, pillikkeet, orvokki) ja eri alueille tyypillisiin lajeihin. Ordinaatiokuvat antoivat selkeämmän kokonaiskuvan rikkakasvien esiintymisestä ja ympäristötekijöiden vaikutuksesta kuin aiemmin samasta aineistosta julkaistu regressiotarkastelu. 